\title{
Unemployment and Gross Domestic Product: Evidence from Papua New Guinea
}

\section{Cahya Purnama Asri ${ }^{1}$}

${ }^{1}$ Entrepreneurship Departemen, Faculty of Economics, Universitas Widya Mataram Yogyakarta, Indonesia

\begin{tabular}{ll}
\hline ARTICLE INFO & ABSTRACT \\
\hline ISSN: 2723-1097 & $\begin{array}{l}\text { The principal link through which economic growth is transmitted to the poor is the } \\
\text { amount of employment it generates which derives from the fact that labour is about } \\
\text { the only resource in which the poor are relatively abundant, thus, for the poor, the } \\
\text { productive use of their plentiful factor, labour, is the principal way to overcome } \\
\text { poverty. There are many factors that afeect gross domestic product, such as } \\
\text { unemployment. The objective of this research is to determine the influence of }\end{array}$ \\
$\begin{array}{l}\text { Unemployment; gross } \\
\text { domestic productingent } \\
\text { Papua New Guinea } \\
\text { research uses quantitative methods and linear regression analysis. The results of } \\
\text { the analysis show that there is significant influence of unemployment on GDP in } \\
\text { Papua New Guinea for the period 1991 - 2019. The influence of unemployment on } \\
\text { GDP in Papua New Guinea is significant because of the small number of people } \\
\text { and most of them are workers, unemployment is very influential on GDP. }\end{array}$ \\
\hline
\end{tabular}

\section{Introduction}

In 1962 Arthur Okun documented that U.S. unemployment tended to fall by 1 percentage point for every 3-percentage point rise in gross national product (i.e., output); observers subsequently dubbed this empirical regularity "Okun's law" thus, the United States had an Okun coefficient of 3(Neely, 2010). A large body of empirical research estimating the Okun coefficients has mostly assumed that causality operates in the reverse direction (i.e. changes in output explain variations in unemployment)(Bartolucci et al., 2018).Okun coefficients can change over time because the relationship of unemployment to output growth depends on laws, technology, preferences, social customs, and demographics (Neely, 2010).

Billi (2020) compare the welfare performance of nominal GDP targeting relative to employment targeting, as well as to a conventional Taylor rule (used to calibrate the model)and the optimal monetary policy with commitment (representing an ideal benchmark). Guerard et al. (2020) report on time series modelling and forecasting using several US. leading economic indicators (LEI) as an input to forecasting real US. GDP and the unemployment rate and the results are greatly supportive of the significance for modelling and forecasting of the suggested input variables and they imply considerable improvements over all traditional benchmarks. Epstein et al.,

Journal of Businessand Management Review Vol. 2 No. 82021 Page 544-557

DOI: $10.47153 /$ jbmr28.1982021

*Corresponding Author

Email address: cahyapurnama.uwm@gmail.com 
(2019) use a key variable that include in their analysis and that makes the point exceedingly clear is unemployment, more specifically, while the initial responses of GDP, investment, and unemployment to a temporary adverse global financial risk shock are very similar between country groups, the medium-run responses of these domestic variables - most notably unemployment - are ultimately more subdued and exhibit considerably less propagation in emerging market economies (EMEs) compared to small open advanced economies (SOAEs).

Economists have long noted that most industrialized countries have larger Okun coefficients than do the United States and - to a lesser extent-Canada and the United Kingdom, in other words, most industrialized countries' unemployment rates tend to vary less for a given gross domestic product (GDP) fluctuation than does that of the United States. The usual explanation for this is that the United States, Canada, and the United Kingdom have less heavily regulated labor markets in which businesses can more easily lay people off during slowdowns and most countries have some combination of stronger implicit social job protections (e.g., Japan), stronger unions, or greater formal restrictions on releasing workers (Neely, 2010). Prior researches didn't discuss unemployment in Papua New Guinea. This research presents novel about unemployment in Papua New Guinea, that related with gross domestic product.

\section{Literature Review}

Teimouri \& Zietz (2018) found that surges in high income countries do not magnify the trend toward deindustrialization. The persistent decline in the investment to GDP ratio and the rise in the overall unemployment rate suggest that surges may negatively affect longer run growth prospects and employment opportunities in these countries, and in middle income Asian countries, surges tend to induce deindustrialization in both output and employment in the medium run, but they do not lower the investment to GDP ratio, while in middle income Latin America, surges speed up deindustrialization, lower investment and raise economy-wide unemployment (Teimouri \& Zietz, 2018). Horvath \& Zhong (2019) quantifies the impact of three key external shocks - external demand, interest rate, and uncertainty shocks - on emerging market economies (EMEs) and find that external shocks have a sizeable impact on macroeconomic fluctuations in EMEs and that a considerable fraction of this impact is through the domestic stock market. A decrease in external demand and an increase in external interest rate and uncertainty lead to a higher unemployment rate, lower stock market return, and a depreciation of the domestic currency and the EMEs' monetary policy actively responds to external shocks and dampens their impact on domestic activity.

Epstein \& Finkelstein Shapiro (2019) document a negative and significant relationship between domestic financial development and unemployment volatility in developing and emerging economies (DEMEs)and the absence of such relationship in advanced economies (AEs). A business cycle labor search model with firm heterogeneity, collateral constraints, and interfirm input credit capital can 
quantitatively rationalize these facts, and greater financial development is associated with lower usage of input credit capital, greater bank credit, and greater capital accumulation, all of which make firms more resilient in the presence of financial shocks.

Charalampidis (2020) studies the recurrent sources of unit-root unemployment fluctuations in Greece, Italy, Portugal, Spain, and the Euro Area by integrating wage markup and labor disutility shocks that exhibit permanent euro-area-wide shifts, country-specific trend developments, and stationary changes in an estimated DSGE model, and in all economies, these labor market shocks account for a negligible share of unemployment cycles, therefore demand shocks explain about $40 \%$ of them, contribute to the pre-crisis convergence of unemployment rates, and shape the unemployment spikes during the Great Recession, and cross-country relative price distortions and supply factors account for about $40 \%$ and $20 \%$ of those cycles, respectively. Gorry et al. (2020) illustrate that even with high worker flows between employment and unemployment, slow movements in the composition of workers across groups with different baseline unemployment rates can generate substantial persistence, and when the model is calibrated to match empirical evidence on labor market outcomes that vary with tenure and worker displacement, the model endogenously generates substantial persistence in unemployment.

Lepetit (2020) show that a quantitatively significant trade-off between inflation and unemployment stabilization arises in New Keynesian models with search and matching frictions in the labor market when both steady-state distortions and the elasticity of labor market tightness with respect to productivity are large, the first condition implies that variations in average unemployment matter for welfare outcomes, and in combination with the unemployment asymmetries built in the search and matching framework, the second condition entails that average unemployment is substantially higher in an economy with business cycles than in steady state. In this environment, the central bank has an incentive to tolerate some inflation volatility in response to shocks since doing so reduces unemployment volatility and average unemployment, most of the welfare gains obtained by the optimal policy derive from this effect on the average level of unemployment (Lepetit, 2020). Arranz \& GarcíaSerrano, (2020) examines whether changes in the potential duration of unemployment benefits influence the entry of older workers into unemployment insurance and analyse empirically the changes in the age pattern of inflows intro unemployment insurance before and after the reform, on the one hand, and the effect of the legal change on the age at the date of unemployment benefit admission, on the other hand, and findings suggest that reducing the potential benefits duration affects the pattern of admissions, transferring entries to higher ages, and that the age at which older workers begin to receive unemployment insurance benefits increase by between one and three months for certain categories of workers.

Broulíková et al. (2020) proposes that the privatization of public housing in Central and Eastern Europe after the fall of the Iron Curtain was a substantial policy shock that 
generated largely exogenous assignment of homeownership to individual households, and this facilitates a new test of the effects of homeownership on mobility and unemployment, and the empirical results do not reject that home ownership reduces mobility, finally the results are inconsistent with homeownership increasing unemployment. Carrère et al. (2020) embed a model of the labour market with sectorspecific search-and-matching frictions into a Ricardian model with a continuum of goods to show that trade reduces unemployment tin countries with comparative advantage in sectors with more efficient labour markets and leads to higher unemployment in countries with comparative advantage in sectors with less efficient labour markets, and the results also help reconcile the apparently contradicting evidence in the empirical literature on the impact of trade on unemployment.

Clymo (2020) using a search and matching model featuring endogenous capital accumulation, rising discount rates have a direct effect on unemployment, since hiring is an investment activity for firms in the presence of search frictions, and an indirect effect, since a rise in discounts reduces investment in capital, reducing the marginal product of labour and hence incentives to hire, and estimate changes in discount rates during the Great Recession using data on both stock markets and investment. Discounts measured from the stock market increase by more but recover faster, while discounts for capital investment increase by less but more persistently, and combined, the two discount measures can account for $52 \%$ of the peak rise in unemployment during the Great Recession, finally, while capital discounts affect unemployment by changing labour productivity, their importance cannot be inferred from observed movements in labour productivity alone, and capital discounts raised unemployment even while observed labour productivity was rising. Couch et al. (2020) provides early evidence of the impacts of the COVID-19 pandemic on minority unemployment in the United States, and non-linear decompositions show a favourable industry distribution partly protected black employment during the early stages of the pandemic, but that an unfavourable occupational distribution and lower average skills levels placed them at higher risk of job losses. An unfavourable occupational distribution and lower skills contributed to a sharply widened Latinx-white unemployment gap that moderated over time as rehiring occurred, and the findings of disproportionate impacts on minority unemployment raise important concerns regarding lost earnings and wealth, and longer-term consequences of the pandemic on racial inequality in the United States.

Esche (2020) investigates the impact of unemployment on couples' overall life satisfaction, as well as both partners' satisfaction in specific life domains, and the results confirm that job loss is harmful to both partners' life satisfaction, therefore, in line with gender role models, the costs of unemployment are significantly higher in couples in which the male partner is unemployed and these differences are much more pronounced in West Germany than in East Germany. Hashimoto et al. (2020) shows that the presence of asset bubbles correct allocative inefficiency regarding production resources, relocating investment resources from low-productivity agents to highproductivity agents, accordingly, the presence of asset bubbles can promote capital 
accumulation, and as capital accumulates and output increases, the number of vacant positions increases because firms acquire more funds to cover a search cost, finally as a result, firms are incentivized to increase employment, however, extrinsic uncertainty may burst asset bubbles and cause a self-fulfilling financial crisis, which is followed by increased unemployment. Kong \& Prinz, (2020) leverage the high-frequency search data to separately identify the effects of multiple NPIs that were introduced around the same time, and then describe a set of assumptions under which proxy outcomes can be used to estimate a causal parameter of interest when data on the outcome of interest are limited, and finally found that between March 14 and 28, restaurant and bar limitations and non-essential business closures can explain $6.0 \%$ and $6.4 \%$ of UI claims respectively, while the other NPIs did not directly increase own-state UI claims, therefore this suggests that most of the short-run increase in UI claims during the pandemic was likely due to other factors, including declines in consumer demand, local policies, and policies implemented by private firms and institutions.

Li et al. (2020) established a small open general equilibrium model to investigate the effects of the changes of consumers' unit private mitigation expenditure on the unemployment rate and the urban-rural wage inequality etc. and found that (1) in the capital specific case, the increase of unit private mitigation expenditure will not only increase the urban unemployment rate but also expend the urban-rural wage inequality; (2) in the capital movable case, the conclusions are exactly opposite to that of the capital specific case. Liotti (2020) confirm that the economic crisis has had detrimental effects mostly on young people, moreover, the paper shows no evidence that greater labour market flexibility improves youth unemployment outcomes. Regarding the other control variables, the regional export, Active Labour Market Policies (ALMPs), regional political participation, increase in average wages, private investment and regional productivity contribute to mitigating the impact of a recession on youth and adult unemployment. Nusair (2020) found that the linear ARDL model suggests that, although oil price changes have no or minor short-run effect on the unemployment rates, they have a significant and positive long-run effect in all the cases, and the NARDL model gives a different picture for the effect of oil price changes on the unemployment rates,while only falling oil prices have a significant short-run effect on the unemployment rates, rising and falling oil prices have a significant and positive long-run effect in all the cases, and finally the results suggest significant evidence of asymmetries both in the short-run and long-run with falling oil prices having a larger impact than rising prices. Rözer et al. (2020) estimate how short $(<1$ year) and long term ( $>1$ year) unemployment relates to these network characteristics for men and women, people below and above 50 years of age, and lower and higher educated individuals, and the results idea more-nuanced perspective on the commonly assumed social withdrawal following unemployment.

The growth challenges confronting European economies, including their fiscal structure and imbalances outlines by Halmai (2015), and established that the European model faced a challenge originating in the absence of a convergence mechanism, and this is why the integration mechanism became dysfunctional. Halmai (2015) claimed 
that the "rebirth of convergence is both a challenge to and a precondition of European renewal and reform." and concluded that the imbalances of public finances and a need for sustainable public finances are the sources of conflicts. Some researches work on economic fundamentals and country spreads (Fernández \& Gulan, 2015; Fink \& Schüler, 2015; Mendoza \& Yue, 2012). Horvath \& Zhong (2019) find that external shocks have a sizeable impact on macroeconomic fluctuations in EMEs and that a considerable fraction of this impact is through the domestic stock market, while a decrease in external demand and an increase in external interest rate and uncertainty lead to a higher unemployment rate, lower stock market return, and a depreciation of the domestic currency and the EMEs' monetary policy actively responds to external shocks and dampens their impact on domestic activity. Gilchrist \& Mojon (2018) construct credit risk indicators for euro area banks and non-financial corporations, these are the average spreads on the yield of euro area private sector bonds relative to the yield on German federal government securities of matched maturities, and the indicators are also constructed at the country level for Germany, France, Italy, and Spain, which reveal that the financial crisis of 2008 dramatically increased the cost of market funding for both banks and non-financial firms, and in contrast, the prior recession following the 2000 U.S. dot-com bust led to widening credit spreads of nonfinancial firms but had no effect on the credit spreads of financial firms, and the 2008 financial crisis also led to a systematic divergence in credit spreads for financial firms across national boundaries.

Gross Domestic Product (GDP) is often treated as shorthand for national economic well-being, even though it was never intended to be; it is a measure of (some) of the marketable output of the economy(Aitken, 2019). Gómez-Puig \& Sosvilla-Rivero (2018) investigates the short and the long run impact of public debt on economic growth, and the results suggest different patterns across the euro area (EA) countries and tend to support the view that public debt always has a negative impact on the long-run performance of EA member states, whilst its short-run effect maybe positive depending on the country. Ibragimov \& Ibragimov (2017) addresses these issues by using econometrically justified instrumental variable regression methods, which the results and discussions on practical use of Okun's relationships for evaluation of average effects of economic growth on the unemployment rate, and vice versa; importance of accounting for confidence intervals in applications of Okun's models to economic development analysis and cross-country comparisons and evaluation of effects of crises and other structural shocks on the economies considered, and also discuss in detail the results of formal econometric tests and economic motivation for validity of instrumental variables used in the study, the formal econometric tests, together with economic arguments, allow us to determine the most appropriate Okuntype models for each of the Commonwealth of Independent States (CIS) countries under consideration. Billi (2020) evaluate the welfare performance of a target for the level of nominal GDP in a New Keynesian model with unemployment, accounting for a zero lower bound (ZLB) constraint on the nominal interest rate, nominal GDP targeting is compared to employment targeting, a conventional Taylor rule, and the 
optimal monetary policy with commitment and find that employment targeting is optimal when supply shocks are the source of fluctuations; nominal GDP targeting can outperform substantially employment targeting.

Guerard et al. (2020) test and report on time series modelling and forecasting using several US, leading economic indicators (LEI) as an input to forecasting real US, and GDP and the unemployment rate. These time series have been addressed before, but the results are more statistically significant using more recently developed time series modelling techniques and software, and the LEI are a statistically significant input to real GDP. A similar conclusion is found for the impact of the LEI and weekly unemployment claims series leading the unemployment rate series and the results are greatly supportive of the significance for modelling and forecasting of the suggested input variables and they imply considerable improvements over all traditional benchmarks. Epstein et al. (2019) use a panel structural vector autoregression methodology to study the impact of global financial risk shocks in emerging market economies (EMEs) versus small open advanced economies (SOAEs), and the shortterm responses of GDP, investment, and unemployment are similar in EMEs compared to SOAEs, but their medium-term responses differ considerably. In EMEs the shock propagates less across GDP and investment, and the response of unemployment is prominently more subdued and further analysis suggests that while in EMEs these dynamics can be traced back to the response of country interest rates to global financial risk shocks and to the average degree of firm informality, in SOAEs these factors are not at play.

Fan et al. (2018) use the provincial-level NERI Index of Marketization from 1997 to 2014 and a panel data model to investigate the quantitative contribution of marketoriented reforms to China's total factor productivity (TFP) and economic growth, and the results indicate that marketization reforms contributed1.3 percentage points to China's annual economic growth rate and accounted for 35 percent of the increase in TFP. This means that the institutional reforms significantly improved resource allocation, however, economic transition in China has not yet been completed and sustainability of future growth will depend on further market-oriented reforms. Sengupta \& Puri (2020) showed that the different economic policies of the respective countries had a role to play in explaining the difference in the quantum of the flow and there is an association between FDI and GDP, and in all the cases, FDI is instrumental in enhancing the economic growth of the countries included in the study.

Beckworth \& Hendrickson (2020) show that forecast errors of the output gap by the Federal Reserve can account for up to $13 \%$ of the fluctuations in the output gap, and in addition, the simulations imply that a nominal GDP targeting rule would produce lower volatility in both inflation and the output gap in comparison with the Taylor Rule under imperfect information. Bullard \& Singh (2020) show that nominal GDP targeting continues to characterize optimal monetary policy in this setting, and also analyze the incomplete markets equilibrium that exists when the monetary policy maker pursues a suboptimal policy, and show how an extension to more general 
preferences can limit the ability of the policymaker to provide full insurance to households in this setting. Dai \& Xu (2019) examine the case of nominal GDP targeting, which is a rule-based monetary regime, depending on the degree of conservativeness by the central bank, in a stylized model the choice of different combination of inflation and real GDP targets can still result in an 'inflationary bias', and there also exists the possibility of a 'disinflationary bias'. Formánek (2020) shows that there is no sign of negative impact of renewable energy consumption on GDP growth, while the estimated overall effect is positive and statistically significant, its economic significance is small, and yet, given the data and economies considered, renewable energy consumption does not exert negative influence on economic growth rates.

Gupta \& Minai (2019) measure how close the predictions of GDP growth are to the actual outcome in India, we have calculated three measures of forecast accuracy: mean absolute error (MAE), root mean square error (RMSE) and Theil's U statistic and found that forecast errors suggest that the performance of Reserve Bank of India (RBI) forecasts is favourable compared to other organizations, as well as with respect to the general international standard. Hackler et al. (2020) studies the effects of complying with individual conditions on the borrowing countries' real gross domestic product (GDP) growth rate and the results suggest that real GDP growth rates a redirectly affected by meeting the compliance standards of select loan conditions. Liu et al. (2020) find that the effect of GDP competition on firm investments is significantly positive and also find that GDP competition destroys investment efficiency significantly, especially by increasing overinvestment. Bäurle et al. (2020) found that the factor model structure outperforms the benchmarks in most tests, and in many cases also the Bayesian vector autoregressive model (BVAR), and the analysis of the covariance matrix of the sectoral forecast errors suggests that the superiority can be traced back to the ability to capture sectoral co-movement more accurately. Caporale \& Gil-Alana (2021) shows that the behaviour of US GDP can be captured accurately by a model incorporating both stochastic trends and stochastic cycles that allows for some degree of persistence in the data, both appear to be mean reverting, although the stochastic trend is nonstationary, while the cyclical component is stationary, with cycles repeating themselves every 6-10 years.

Fatima et al. (2020) results outline an intriguing indirect relationship between trade openness and GDP growth, if human capital accumulation (HCA) is taken into account as an intervening variable, trade may have a negative impact on GDP growth when countries exhibit a low level of HCA. Govori \& Fejzullahu (2020) suggest that in Kosovo, remittances are the leading contributor to GDP growth, and could be more valuable if remittances were invested in the manufacturing sector, therefore these investments could have positive effects on job creation, thereby reducing the unemployment rate and Kosovo's dependence on imports. Lee et al. (2020) found that tourism volatility (TV) significantly aggravates GDP volatility (GDPV) in South Africa, the impact varies from year to year and is greatest during the periods characterized by economic turbulence and crime and violence against foreigners, and the size of the 
coefficients has been on a steady increase over time, reflecting the growing importance of tourism and TV to the South African economy.

Patatoukas (2020) found that the univariate association between stock returns and gross domestic product (GDP) growth forecast surprises is indistinguishable from zero, although consistent with prior macro-finance research, this phenomenon is intriguing if one believes that the stock market should move in sync with the economy. U. \& Mitra (2020) reveals that FDI has a positive and significant impact on pollution and GDP attracts FDI, this transitive relation suggests that FDI in pollution-controlling technology would be a feasible solution to sustainable development. VentosaSantaulària et al. (2021) found evidence in favour of the growth rate's being stable around a changing mean, on the one hand, the 1982 debt crisis and 2000 recession coincide with structural changes in the Mexican economy that had a lasting impact (on growth) and permanently lowered potential GDP levels, and on the other, we find no significant damaging effect (on potential GDP) of either the 1995financial crisis or the Great Recession. Canale \& De Siano (2021) show that tourism contributes to the increase of per capita GDP, however, when accounting for the congestion effect, the relation appears to be nonlinear, revealing a detrimental effect on growth driven by an excessive tourism pressure on territories.

\section{Method}

This research uses quantitative methods (Bajpai, 2018) and a case study of Papua New Guinea because researches are rarely done on it. This study uses data form World Bank. This study uses the period 1991 -2019. This study uses linear regression analysis (Bajpai, 2018), because it uses one independent variable and dependent variable each. The independent variable in this study is unemployment. The dependent variable in this study is gross domestic product (GDP). Data in this research collected from the website of the World Bank.

The operational definitions of variables in this study are as follows:

Unemployment : Unemployment data of Papua New Guinea

GDP :GDP data of Papua New Guinea

The research's framework is:

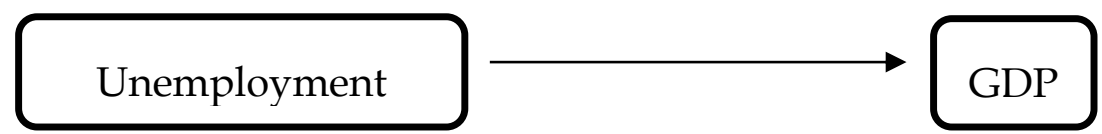

\section{Result and Discussion}


The results of the regression analysis on Y (GDP) are as follows:

Table 1.R square

Model Summary

\begin{tabular}{|c|c|c|c|c|}
\hline Model & $\mathrm{R}$ & R Square & $\begin{array}{l}\text { Adjusted R } \\
\text { Square }\end{array}$ & $\begin{array}{l}\text { Std. Error of } \\
\text { the Estimate }\end{array}$ \\
\hline 1 & $.402^{a}$ & .162 & .131 & $7.576277128 \mathrm{E}$ \\
\hline
\end{tabular}

a. Predictors: (Constant), unemployment

Table 1 shows that $R$ square $=0.162$ which means that variable $X$ (unemployment) explains variable $\mathrm{Y}(\mathrm{GDP})$ by $16,2 \%$ and the remaining $83,8 \%$ is explained by other variables that not examined in this study.

Table 2. The effect of unemployment on GDP

\begin{tabular}{lllllll}
\hline \multirow{2}{*}{ Model } & \multicolumn{2}{c}{$\begin{array}{c}\text { Unstandardized } \\
\text { Coefficients }\end{array}$} & $\begin{array}{c}\text { Standardized } \\
\text { Coefficients }\end{array}$ & $\mathrm{t}$ & \multicolumn{2}{c}{ Sig. } \\
\cline { 2 - 4 } & $\mathrm{B}$ & Std. Error & Beta & & & \\
\hline 1 & $\begin{array}{l}\text { (Constant) } \\
\text { unemploymen } \\
\mathrm{t}\end{array}$ & $3.963 \mathrm{E} 10$ & $1.266 \mathrm{E} 10$ & & 3.129 & .004 \\
& $-1.106 \mathrm{E} 10$ & $4.846 \mathrm{E} 9$ & -.402 & -2.283 & .031 \\
\hline
\end{tabular}

a. Dependent Variable: gdp

Table 1 shows that sig $=0.031$ which means that there is significant influence of unemployment on GDP in Papua New Guinea for the period $1991-2019$. The regression equation is $\mathrm{Y}=39.630 .000 .000-11.060 .000 .000 \mathrm{X}$

The result of the analysis shows that there is significant influence of unemployment on GDP in Papua New Guinea for the period 1991 -2019.This research's results are in line with previous researches (Bartolucci et al., 2018; Billi, 2020; Guerard et al., 2020). The influence of unemployment on GDP in Papua New Guineais significant because of the small number of people and most of them are workers, unemployment is very influential on GDP. The government of Papua New Guinea should create jobs to reduce unemployment and improve the skills of the population by providing trainings.

This research result shows that unemployment affects GDP. This can be used as a reference for the Papua New Guinea government to overcome the unemployment problem, so that it will improve the quality of the people. The government of Papua New Guinea should create jobs to reduce unemployment and improve the skills of the 
population by providing trainings. This study provides a novel in the form of the effect of unemployment on GDP in Papua New Guinea which is rarely discussed by previous researchers.

\section{Conclusion}

The results of the analysis show that there is significant influence of unemployment on GDP in Papua New Guinea for the period 1991 - 2019. The effect of unemployment on GDP in Papua New Guinea is significant because of the small number of people and most of them are workers, unemployment is very influential on GDP. This research result shows that unemployment affects GDP. This can be used as a reference for the Papua New Guinea government to overcome the unemployment problem, so that it will improve the quality of the people. The government of Papua New Guinea should create jobs to reduce unemployment and improve the skills of the population by providing trainings. This study provides a novel in the form of the effect of unemployment on GDP in Papua New Guinea which is rarely discussed by previous researchers.

Future research should investigate about other variables that affect gross domestic product, such as inflation. The research's contribution is identifying the factors that associate with gross domestic product and enable policy makers to make policies related to this research's result. This study has limitations in terms of the time span of the study. Future studies should use a longer time span.

\section{References}

Aitken, A. (2019). Measuring Welfare Beyond GDP. National Institute Economic Review, 249(1), R3-R16. https:/ / doi.org/10.1177/002795011924900110

Arranz, J. M., \& García-Serrano, C. (2020). Does unemployment benefit duration affect inflows into unemployment? The impact of a law change for older workers. Journal of the Economics of Ageing, 17(July), 100278. https://doi.org/10.1016/j.jeoa.2020.100278

Bajpai, N. (2018). Business Research Methods. 362. http:/ / www.amazon.com/BusinessResearch-Methods-2nd-Edition/dp/1741032539

Bartolucci, F., Choudhry, M. T., Marelli, E., \& Signorelli, M. (2018). GDP dynamics and unemployment changes in developed and developing countries. Applied Economics, 50(31), 3338-3356. https:/ / doi.org/10.1080/00036846.2017.1420894

Bäurle, G., Steiner, E., \& Züllig, G. (2020). Forecasting the production side of GDP. Journal of Forecasting, July, 1-23. https:/ / doi.org/10.1002/for.2725

Beckworth, D., \& Hendrickson, J. R. (2020). Nominal GDP Targeting and the Taylor Rule on an Even Playing Field. Journal of Money, Credit and Banking, 52(1), 269-286. https://doi.org/10.1111/jmcb.12602

Billi, R. M. (2020). Unemployment fluctuations and nominal GDP targeting. Economics Letters, 188, 108970. https:/ / doi.org/10.1016/j.econlet.2020.108970

Broulíková, H. M., Huber, P., Montag, J., \& Sunega, P. (2020). Homeownership, 
mobility, and unemployment: Evidence from housing privatization. Journal of Housing Economics, 50(June), 101728. https:/ / doi.org/10.1016/j.jhe.2020.101728

Bullard, J., \& Singh, A. (2020). Nominal GDP Targeting with Heterogeneous Labor Supply. Journal of Money, Credit and Banking, 52(1), 37-77. https://doi.org/10.1111/jmcb.12615

Canale, R. R., \& De Siano, R. (2021). Territorial pressure and tourism contribution to GDP: The case of Italian regions. International Journal of Tourism Research, March, 1-10. https://doi.org/10.1002/jtr.2451

Caporale, G. M., \& Gil-Alana, L. A. (2021). Trends and cycles in macro series: The case of US real GDP. Bulletin of Economic Research, April 2020, 1-12. https://doi.org/10.1111/boer.12278

Carrère, C., Fugazza, M., Olarreaga, M., \& Robert-Nicoud, F. (2020). Comparative advantage and equilibrium unemployment. European Economic Review, 127. https://doi.org/10.1016/j.euroecorev.2020.103496

Charalampidis, N. (2020). On unemployment cycles in the Euro Area, 1999-2018. $\begin{array}{llll}\text { European Economic Review, } 103329 . & \end{array}$ https:/ / doi.org/10.1016/j.euroecorev.2019.103329

Clymo, A. (2020). Discounts, rationing, and unemployment. European Economic Review, 128. https://doi.org/10.1016/j.euroecorev.2020.103518

Couch, K. A., Fairlie, R. W., \& Xu, H. (2020). Early evidence of the impacts of COVID19 on minority unemployment. Journal of Public Economics, 192, 104287. https://doi.org/10.1016/j.jpubeco.2020.104287

Dai, Y., \& Xu, B. (2019). Nominal Gdp Targeting and Central Bank Conservativeness. Bulletin of Economic Research, 1-8. https:/ / doi.org/10.1111/boer.12189

Epstein, B., \& Finkelstein Shapiro, A. (2019). Financial development, unemployment volatility, and sectoral dynamics. Journal of Economic Dynamics and Control, 99, 82102. https:// doi.org/10.1016/j.jedc.2018.11.004

Epstein, B., Finkelstein Shapiro, A., \& González Gómez, A. (2019). Global financial risk, aggregate fluctuations, and unemployment dynamics. Journal of International Economics, 118, 351-418. https:// doi.org/10.1016/j.jinteco.2019.03.005

Esche, F. (2020). Is the problem mine, yours, or ours? The impact of unemployment on couples' life satisfaction and specific domain satisfaction. Advances in Life Course Research, 46(May), 100354. https:/ / doi.org/10.1016/j.alcr.2020.100354

Fan, G., Ma, G., \& Wang, X. (2018). Institutional reform and economic growth of China: 40-year progress toward marketization. Acta Oeconomica, 69, 7-20. https:/ / doi.org/10.1556/032.2019.69.S1.2

Fatima, S., Chen, B., Ramzan, M., \& Abbas, Q. (2020). The Nexus Between Trade Openness and GDP Growth: Analyzing the Role of Human Capital Accumulation. SAGE Open, 10(4). https:/ / doi.org/10.1177/2158244020967377

Fernández, A., \& Gulan, A. (2015). Interest rates, leverage, and business cycles in emerging economies: The role of financial frictions. American Economic Journal: Macroeconomics, 7(3), 153-188. https://doi.org/10.1257/mac.20120141

Fink, F., \& Schüler, Y. S. (2015). The transmission of US systemic financial stress: Evidence for emerging market economies. Journal of International Money and 
Finance, 55, 6-26. https:/ / doi.org/10.1016/j.jimonfin.2015.02.019

Formánek, T. (2020). Semiparametric spatio-temporal analysis of regional GDP growth with respect to renewable energy consumption levels. Applied Stochastic Models in Business and Industry, 36(1), 145-158. https:// doi.org/10.1002/asmb.2445

Gilchrist, S., \& Mojon, B. (2018). Credit Risk in the Euro Area. Economic Journal, 128(608), 118-158. https:/ / doi.org/10.1111/ecoj.12427

Gómez-Puig, M., \& Sosvilla-Rivero, S. (2018). Public debt and economic growth: Further evidence for the euro area. Acta Oeconomica, 68(2), 209-227. https:/ / doi.org/10.1556/032.2018.68.2.2

Gorry, A., Munro, D., \& vom Lehn, C. (2020). Experience, skill composition, and the persistence of unemployment fluctuations. Labour Economics, 63(December 2019). https:/ / doi.org/10.1016/j.labeco.2019.101793

Govori, F., \& Fejzullahu, A. (2020). External Financial Flows and GDP Growth in Kosovo. Journal of Developing Societies, 36(1), 56-76. https:/ / doi.org/10.1177/0169796X19898964

Guerard, J., Thomakos, D., \& Kyriazi, F. (2020). Automatic time series modeling and forecasting: A replication case study of forecasting real GDP, the unemployment rate and the impact of leading economic indicators. Cogent Economics and Finance, 8(1). https:/ / doi.org/10.1080/23322039.2020.1759483

Gupta, M., \& Minai, M. H. (2019). An Empirical Analysis of Forecast Performance of the GDP Growth in India. Global Business Review, 20(2), 368-386. https:/ / doi.org/10.1177/0972150918825207

Hackler, L., Hefner, F., \& Witte, M. D. (2020). The Effects of IMF Loan Condition Compliance on GDP Growth. American Economist, 65(1), 88-96. https:/ / doi.org/10.1177/0569434519836994

Halmai, P. (2015). Structural Reforms and Growth Potential in the European Union. Public Finance Quarterly, 60(4), 510-525.

Hashimoto, K. ichi, Im, R., \& Kunieda, T. (2020). Asset Bubbles, Unemployment, and a Financial Crisis. Journal of Macroeconomics, 65(May), 103212. https://doi.org/10.1016/j.jmacro.2020.103212

Horvath, J., \& Zhong, J. (2019). Unemployment dynamics in emerging countries: Monetary policy and external shocks. Economic Modelling, 76(October 2017), 3149. https:// doi.org/10.1016/j.econmod.2018.07.017

Ibragimov, M., \& Ibragimov, R. (2017). Optimal portfolio choice under a liability constraint. Applied Economics, 49(34), 3453-3479. https:/ / doi.org/10.1023/A

Kong, E., \& Prinz, D. (2020). Disentangling policy effects using proxy data: Which shutdown policies affected unemployment during the COVID-19 pandemic? $\begin{array}{llll}\text { Journal of Public } & 104257 .\end{array}$ https://doi.org/10.1016/j.jpubeco.2020.104257

Lee, C.-C., Olasehinde-Williams, G. O., \& Olanipekun, I. O. (2020). GDP volatility implication of tourism volatility in South Africa: A time-varying approach. $\begin{array}{lll}\text { Tourism Economics, } & 135481662097000 .\end{array}$ https:/ / doi.org/10.1177/1354816620970001

Lepetit, A. (2020). Asymmetric unemployment fluctuations and monetary policy 
trade-offs. Review of Economic Dynamics, 36, 29-45. https://doi.org/10.1016/j.red.2019.07.005

Li, X., Fu, H., \& Wu, Y. (2020). Pollution mitigation, unemployment rate and wage inequality in the presence of agricultural pollution. China Economic Review, 61(June 2019), 101425. https:/ / doi.org/10.1016/j.chieco.2020.101425

Liotti, G. (2020). Labour market flexibility, economic crisis and youth unemployment in Italy. Structural Change and Economic Dynamics, 54, 150-162. https:/ / doi.org/10.1016/j.strueco.2020.04.011

Liu, Q., Hao, Y., Du, Y., \& Xing, Y. (2020). GDP competition and corporate investment: Evidence from China. Pacific Economic Review, 25(3), 402-426. https:/ / doi.org/10.1111/1468-0106.12312

Mendoza, E. G., \& Yue, V. Z. (2012). A general equilibrium model of sovereign default and business cycles. Quarterly Journal of Economics, 127(2), 889-946. https:/ / doi.org/10.1093/qje/qjs009

Neely, C. J. (2010). Okun's Law: Output and Unemployment. Economic Synopses, 2010(4), 2009-2010. https:/ / doi.org/10.20955/es.2010.4

Nusair, S. A. (2020). The asymmetric effects of oil price changes on unemployment: Evidence from Canada and the U.S. Journal of Economic Asymmetries, 21(December 2019), e00153. https://doi.org/10.1016/j.jeca.2019.e00153

Patatoukas, P. N. (2020). Stock Market Returns and GDP News. Journal of Accounting, Auditing and Finance. https:/ / doi.org/10.1177/0148558X20913418

Rözer, J. J., Hofstra, B., Brashears, M. E., \& Volker, B. (2020). Does unemployment lead to isolation? The consequences of unemployment for social networks. Social Networks, 63, 100-111. https:/ / doi.org/10.1016/j.socnet.2020.06.002

Sengupta, P., \& Puri, R. (2020). Exploration of Relationship between FDI and GDP: A Comparison between India and Its Neighbouring Countries. Global Business Review, 21(2), 473-489. https://doi.org/10.1177/0972150918760026

Teimouri, S., \& Zietz, J. (2018). The impact of surges in net private capital inflows on manufacturing, investment, and unemployment. Journal of International Money and Finance, 88, 158-170. https://doi.org/10.1016/j.jimonfin.2018.07.007

U., T. S. C., \& Mitra, A. (2020). Development and Degradation: The Nexus between GDP, FDI, and Pollution in India. Emerging Economy Studies, 6(1), 39-49. https:/ / doi.org/10.1177/2394901520907712

Ventosa-Santaulària, D., Hernández-Román, L. G., \& Amezcua, A. V. (2021). Recessions and potential GDP: The case of Mexico. Bulletin of Economic Research, 73(2), 179-195. https:// doi.org/10.1111/boer.12241 